\title{
LONGSTANDING DERMATOFIBROSARCOMA PROTUBERANS- A CASE REPORT
}

\author{
Sanjeev Sharma1, Babulal Sunkaria², Chithra Thomas³, Jayant Dhamor 4
}

1 Professor, Department of Surgery, GMC, Amritsar, Punjab, India. ${ }^{2}$ Associate Professor, Department of Surgery, GMC, Amritsar, Punjab, India. 3 Junior Resident, Department of Surgery, GMC, Amritsar, Punjab, India. 4Junior Resident, Department of Surgery, GMC, Amritsar, Punjab, India.

HOW TO CITE THIS ARTICLE: Sharma S, Sunkaria B, Thomas C, et al. Longstanding dermatofibrosarcoma protuberans- a case report. J. Evolution Med. Dent. Sci. 2019;8(05):339-340, DOI: 10.14260/jemds/2019/74

\section{PRESENTATION OF CASE}

A 42-year-old male presented to surgical OPD with a slow growing painless swelling in the left inguinal region since 3 years. He did not have history of similar swellings anywhere in the body. He did not have history of cough, fever, weight loss or any neurological deficits on the limb. On examination, the swelling was about $10 \times 8 \mathrm{cms}$. on the left inguinal region with irregular margins, uneven surface, reddish discolouration, with no local rise of temperature and with areas of pressure necrosis.

\section{CLINICAL DIAGNOSIS}

Soft Tissue Selling of Inguinal Region.

\section{DIFFERENTIAL DIAGNOSIS}

- Inguinal Adenitis

- Lymphoma

- Metastatic Neoplasm

- Liposarcoma

- Fibrosarcoma

- Dermatofibrosarcoma Protuberans

\section{PATHOLOGICAL DISCUSSION}

Dermatofibrosarcoma is a rare locally invasive soft tissue sarcoma with a propensity for extensive subclinical involvement local invasion which may include subcutaneous tissue, muscle, fascia and bone. The growth pattern of DFSP resembles that of fibroblasts with pseudopod like extensions from a central mass that penetrate tissue over a time. ${ }^{1}$ Histologically, DFSP is characterised by a fibroblastic proliferation of tumour cells arranged around a central storiform pattern. ${ }^{2}$ DFSP tumour cells exhibit a chromosomal translocation of genes COL1A9 and PGDF $\beta(t 17,22)$ which encode to alpha chain of type I collagen and beta chain of platelet derived growth factors. ${ }^{3}$ In the last several decades, Mohs surgery has emerged as a promising treatment option and achieves superior results to surgical excision. ${ }^{4}$ It provides a method of eradicating tumour that rests on intraoperative evaluation of tumour margins.

'Financial or Other Competing Interest': None.

Submission 20-12-2018, Peer Review 21-01-2019,

Acceptance 28-01-2019, Published 04-02-2019.

Corresponding Author:

Dr. Chithra Thomas,

NRI Girls Hostel,

GMC, Amritsar,

Punjab, India.

E-mail: chithrathomas90@gmail.com

DOI: $10.14260 /$ jemds/2019/74
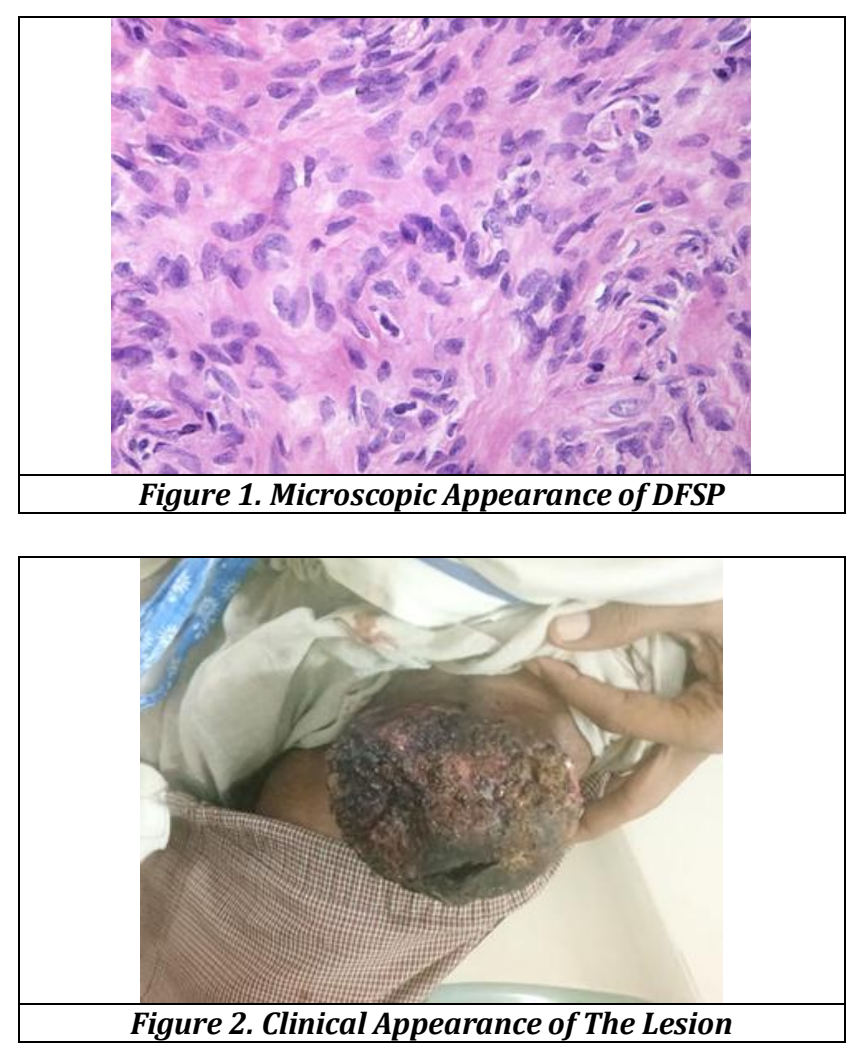

\section{DISCUSSION OF MANAGEMENT}

He underwent a wide local excision with primary closure and the specimen was sent for HPE examination HPE examination which showed spindle cells arranged in storiform pattern with deep margin showing tumour tissue and concluded it to be dermatofibrosarcoma protuberans. The patient was referred to radiotherapy and is on follow up there.

DFSD is a low grade soft tissue sarcoma described in 1924 by Darier and Ferdnand. 5 It accounts for $0.1 \%$ of all malignancies with and annual incidence of $0.8 \%$ million. ${ }^{6} \mathrm{~A}$ slight male preponderance has been reported. ${ }^{7}$ The tumour has lower chances of metastasis but is aggressive locally. ${ }^{8}$ The tumour commonly presents or a slow growing asymptomatic, skin-color, plaque that eventually turns to reddish or violaceous nodules MMS is the treatment of choice for DFSP. Prior to MMS, surgical excision with $3 \mathrm{cms}$ to $5 \mathrm{cms}$ vide margins was recommended but associated with high rates of local recurrence. A recurrence rate of up to 20 percent with $3 \mathrm{~cm}$ surgical margins has been described. ${ }^{9}$

Radiotherapy has been used as an adjuvant therapy after wide surgical excision or in those patients who have inoperable disease. Post-operative radiotherapy has been associated with a cure rate of $>85$ percent. ${ }^{10}$ 


\section{FINAL DIAGNOSIS}

Dermatofibrosarcoma Protuberans

\section{REFERENCES}

[1] Robinson JK. Dermatofibrosarcoma protuberans resected by Mohs' surgery (Chemosurgery). A 5-year prospective study. J Am Acad Dermatol 1985;12(6):1093-8.

[2] Gloster HM Jr. Dermatofibrosarcoma protuberans. J Am Acad Dermatol 1996;35(3 Pt 1):355-74, quiz 3756.

[3] Fiore M, Miceli R, Mussi C, et al. Dermatofibrosarcoma protuberans treated at a single institution: a surgical disease with a high cure rate. Journal of Clinical Oncology 2005;23(30):7669-75.

[4] DuBay D, Cimmino V, Lowe L, et al. Low recurrence rate after surgery for dermatofibrosarcoma protuberans: a multidisciplinary approach from a single institution. Cancer 2004;100(5):1008-16.
[5] Beech DJ, Long AB, Long WP. Dermatofibrosarcoma protuberans and breast cancer: genetic link or coincidental association? Am Surg 2004;70(6):543-5.

[6] Stojadinovic A, Karpoff HM, Antonescu CR, et al. Dermatofibrosarcoma protuberans of the head and neck. Ann Surg Oncol 2000;7(9):696-704.

[7] Asquo ME, Umoh MS, Ebughe G. Dermatofibrosarcoma protuberans: case reports. Ann Afr Med 2007;6(2):803.

[8] Nouri K, Lodha R, Jimenez G, et al. Mohs micrographic surgery for dermatofibrosarcoma protuberans: University of Miami and NYU experience. Dermatol Surg 2002;28(11):1060-4.

[9] Thomas CJ, Wood GC, Marks VJ. Mohs micrographic surgery in the treatment of rare aggressive cutaneous tumors: the Geisinger experience. Dermatol Surg 2007;33(3):333-9.

[10] Mendenhall WM, Zlotecki RA, Scarborough MT. Dermatofibrosarcoma protuberans. Cancer 2004;101(11):2503-8. 